\title{
A Reading of the Canons of Laon Story
}

Amid the plethora of tales and episodes related to saints in European literature, relic tales are one category that is by and large associated with a localized religiosity rather than a universal reverence. Significantly, these are stories linked to and promoted by those Church institutions that preserve the relics concerned. However, in some instances, there is a demand for implanting translated relic tales into literatures distant from the establishment that produced them. One is tempted to hypothesize on the causes behind such translations and speculate on whether they can be seen as arguments for or against matters that are being debated in the target language. In the case of Iceland, relics of a foreign origin are rarely mentioned in vernacular sources and relic tales are mostly found in the sagas of the three Icelandic saints, Porlákur, Jón, and Guðmundur. In Maríu saga, a collection of miracles from various manuscripts edited by C.R. Unger in 1871, we find the story of the canons of Laon, a translated medley of tales where relics play a large part (Mariu saga: 639-654). This is an exception to the regional emphasis of most relic tales, and it seems worthwhile to consider how this text reflects Icelandic society at the time of its translation.

The story of the canons of Laon is an account of two fundraising tours carried out in order to rebuild a cathedral that was burned down in a riot. It is presumably based on real events that happened in the wake of a revolt in 1112 when the people of Laon turned against their bishop, Waldric, and burned down his house. The burning of the cathedral was unintentional and happened by accident. The translated text is somewhat unclear about how this all came about; it simply says that Bishop Waldric wanted to "prevent the townsfolk from keeping that oath they had wrongly sworn". We are not told what oath or why it was wrongly sworn. It is an abrupt beginning, and the narrator seems eager to get to his main concern, the ensuing travel story. There is actually an even earlier prelude to the narrative. It all begins with a murder in the cathedral of Laon, where a certain Gérard of Quierzy is brutally killed by his enemies while he is kneeling in prayer. As with the revolt against Bishop Waldric, we are not given the backstory; we have practically no idea who this Gérard is or what he did to deserve his harsh fate. But Gérard's blood is spilled on the church floor and cannot be washed off. Anselm, dean of the cathedral, is said to have secretly whispered to his assistants that he was afraid that Gérard's blood could never be washed off unless the cathedral was purged by fire. So, when the revolt against Bishop Waldric breaks out and the flames engulf the cathedral of Laon, it is not a complete misfortune. The cathedral had already been blemished by the spilling of innocent blood, and the overall motivation behind our story is the need to build a new cathedral in Laon.

Hjalti Snær Agisson, University of Iceland

Ә Open Access. (C 2021 Hjalti Snær Ægisson, published by De Gruyter. (c) BY-NC-ND This work is licensed under the Creative Commons Attribution-NonCommercial-NoDerivatives 4.0 International License.

https://doi.org/10.1515/9783110695366-005 
Seven canons of Laon are selected to go on a journey around northern France to collect money for the enterprise. To guarantee their collection takings, the canons bring with them the holy relics from the old cathedral, and various miracles occur during their travels. It is the opposite of pilgrimage: not people travelling to relics but the relics travelling to the people. The tour around Northern France is quite successful; large sums of money are collected, and some serious construction work takes place in Laon during the next winter. The funding falls short, however, and the next spring, it has become clear that the project has exceeded its budget. Consequently, another group of canons is put together to go on a second fundraising tour, this time to England. Much like the first tour, the England tour is full of marvels and astounding happenings that move bystanders to open their wallets and make sumptuous donations to the travelling fellowship. The canons return to Laon, and their takings are sufficient to finish the construction of the new cathedral.

Before analysing the story in more detail, it is worth considering what source is behind the Old Norse translation. The story of the canons of Laon is reported by two contemporary historians and one who came approximately a century later. First, there are the Monodies of Guibert of Nogent, composed in 1115, when the canons of Laon had only recently returned from their wanderings (Archambault 1996). This is the best available account of the events that led to the destruction of the cathedral of Laon. Guibert describes the actions of Gérard of Quierzy and Waldric the bishop in much more detail than the Old Norse translator. ${ }^{1}$ It is a fascinating text for several reasons, not least because of its classical connotations: Guibert labels the events in Laon as a "tragedy" (tragoedia), which is an uncommon word in early twelfth-century Latin. The man who gives shelter to Gérard's murderers is compared to Catiline, as if to underline his wickedness. Guibert is extremely judgemental of the whole thing; he sees the revolt in Laon as a dirty war with no real heroes, and strongly implies that the fundraising tours are based on a false premise. Around five years later, Guibert would compose an essay called De sanctis et eorum pigneribus (On Saints and their Relics), where he explicates his views on the whole practice of promoting relics for financial gain (Head 2001: 399-427). In this text, Guibert acknowledges that he was present at one of the early stops in France when the canons of Laon were starting their first tour, and he regrets not having exposed their hyperbolic portrayals of relics that were allegedly not as holy as they claimed.

Second, there are The Miracles of St Mary of Laon by Hermann of Laon, also known as Hériman of Tournai (Hermanni Monachi: 961-1018). The double name stems from the fact that Hermann served as abbot and chronicler at the abbey of St Martin of Tournai, but he was expelled from there in 1136 and spent the rest of his life wandering from one place to another. He spent some time in Laon and wrote

1 A fine overview of book 3 of the Monodies, where the events in Laon are described, is found in Rubenstein (2002: 101-110). 
this work, which is probably the reason for him being associated with Laon. This account was composed at some time in the 1140s, and it is constructed as an eyewitness testimony, a first-person narrative of one of the canons from the travelling group. Third, there is the Chronicon of Hélinand of Froidmont, compiled between 1211 and 1223. This is one of the sources of, and perhaps a major model for, the colossal Speculum Historiale by Vincent of Beauvais, composed a few years later, a well-known text in Iceland and quoted by several authors of historical and hagiographical translations. Gabriel Turville-Petre assumed in 1959 that Hermann's text was the source of the Old Norse translator, but Ole Widding suggested in 1996 that Hélinand's Chronicon is a more likely candidate (Turville-Petre 1959: 111; Widding 1996: 71). At first glance, the differing views are not surprising, because Hélinand in fact incorporates large parts of Hermann's text, abridging it generously. Guibert's version is different, and can easily be ruled out. The translator actually names his source in the beginning: Svo segir Helimandr munkur [. . .] 'Thus says Helimandur the monk [. . .]' (Mariu saga: 639). Unger modified the name Helimandr as Helinan$d u s$, and it only takes few minutes of reading to realize that the Icelandic translation is much closer to the Hélinand version; most of it can be matched word by word to Hélinand's text. Hermann's text is longer and has a strong tendency to attach biblical citations to his descriptions - comparing, for example, the burning of Laon to the fall of Jerusalem - something not found in the Icelandic text. Hermann also includes various details, like the names of the travelling canons and several names of the people they meet. This is absent from Hélinand's abridged version and consequently not found in the Icelandic text. One can therefore safely assume that the translation is based on Hélinand's rather than Hermann's account.

When estimating the date of the Old Norse translation, both the manuscript tradition and a comparison with related translations should be taken into account. The translated text is preserved in two manuscripts: Holm perg 14 to (1450-1500) and AM 635 4to (early eighteenth century). The more recent manuscript was written by Eyjólfur Björnsson (1666-1746), one of those painstaking scribes who circulated around Árni Magnússon and faithfully reproduced every archaic word-form they found in their text. This has led people to believe that the exemplar behind the surviving fifteenth-century manuscript was probably older than it (Turville-Petre 1959: 112). One of the miracles included in the collection (in which the canons of Laon are included) is dated to 1330 , which must therefore be the terminus post quem. We can get somewhat closer to dating the translation by considering two other translations for which Hélinand's Chronicon is the reference point. One of them is a biography of St Nicholas, Nikuláss saga erkibyskups 2 by Bergur Sokkason, a composite work based on a variety of sources. Early in his saga, Bergur provides three positions on the qualities of God, and then adds a story to illustrate each of them. Bergur's second statement is that God sometimes resorts to supernatural events to scare humans into behaving well. The exemplum Bergur presents as his case in point is borrowed from the narrative of the canons of Laon. It is an incident that takes place in Christchurch, where 
the canons get an unfriendly reception from the local clergy, who only reluctantly let them place their relics in a distant side-chapel in the cathedral. When it turns out that the townsfolk are much more interested in donating their alms to the visitors from Laon than their own church, the canons are thrown out and left to wander in the pouring rain. It is a motif that gets repeated in the narrative; the canons of Laon are frequently met with hostility because they are suspected by the local ministry of undermining their source of income. After the canons have moved out of the town, God's anger towards the dean of Christchurch is expressed in a straightforward way when a fire-breathing dragon attacks his home and the cathedral, reducing both to ashes sva at engi sa ormul eptir 'so no trace of it could be discerned' (Heilagra manna søgur 2: 58).

The other significant benchmark when dating the Old Norse translation of the canons of Laon story is an ævintýri (i.e. a short sermon-tale) called "Af skólaklerk", preserved in the manuscript AM 657 a-b 4to (Islendzk æeventyri 1: 153-154). It is a simple dream narrative where a student from an unspecified school dreams that he is on his way to a city but has to cross a river to get there. He sees Christ and the Apostles washing their clothes in the river, and when he asks them if they know where to cross the stream, they tell him that he will not be able to do so unless he washes his clothes first. The washing is explicated as a metaphor for doing penance. When the boy wakes up, he goes for a walk in the woods and knocks on the door of a newly established monastery, where he is received by twelve monks who look exactly like the Apostles from his dream. Deciphering the dream as a wake-up call from God, the student decides to enter the monastery, where he stays for the rest of his life. Not only is this tale extracted from Hélinand's Chronicon - it is situated there in book 47, just before the narrative of the canons of Laon in book 48. Since Bergur Sokkason is believed to have died around 1350 and the manuscript AM $657 \mathrm{a}-\mathrm{b}$ 4to is dated to around the same time, we can safely assume that Hélinand's Chronicon was circulating in Iceland in the mid- to late fourteenth century.

The overall moral of the Laon narrative is to encourage kindness towards visitors and reverence for holy relics. However, some more specific conclusions can be drawn in those cases where the translation is made to reflect contemporary issues in Iceland during the period of composition. By selecting this particular sequence from Hélinand's Chronicon and concentrating on canons regular as subject matter in a serious story, the translator is indirectly making observations about an office that had become increasingly important for public affairs in Iceland. The canons of Niðarós came to real prominence in Lárentíus saga and can be considered a major object of interest within that saga as a whole. When Lárentíus Kálfsson (1267-1331), future bishop of Hólar, travels to Niðarós as a young man in 1294, he gets involved in a conflict between the canons regular and Archbishop Jörundur. The origin of the dispute is not clarified in the saga, but it obviously relates to the distribution of power between the two institutions. Lárentius is assigned by the archbishop to read a letter in which three of the canons regular are excommunicated for refusing to comply with 
their lawful superior. Since Jörundur does not appear to have the nerve to read out the denouncement himself, Lárentius's deed is seen as an act of bravery. It haunts him for a long time; years later, when Jörundur Porsteinsson, bishop of Hólar, is humiliated by Lárentíus in a quarrel over inheritance issues, Jörundur falsely accuses Lárentius of forging documents in order to afflict the chapter. Enraged, the canons throw Lárentíus into a dungeon where he is kept for a whole winter. Subsequently, he is sent to Iceland in chains, where Jörundur Porsteinsson temporarily deprives him permission to chant Mass. This fierceness reverberates throughout the story, and the author of Lárentíus saga portrays the new power elite at Niðarós as a highly perilous and unpredictable force.

Lárentius saga was composed at approximately the same time as the episode about the canons of Laon was translated. ${ }^{2}$ When comparing the two texts, it is tempting to see the Laon narrative as a normative description of how canons regular are supposed to perform their duties as loyal servants of a chapter. The canons in Lárentíus saga overstep their limits and go beyond what is appropriate for their place in the larger ecclesiastical scheme. Yet such a reading is slightly confounded when the aggravating qualities of the canons of Laon are considered. In many of the towns they visit, the canons clash with the local clergy, but the narrator never hints that the deans and bishops who are offended by visitors collecting money within their diocese actually have a right to object to what they see as an unwelcome intrusion. The fundraising project of Laon is given complete priority over everyday matters in each region. At every destination, a number of maimed, mute, blind, and disabled people are drawn to the canons and donate alms. It seems that simply by standing or lying close to the holy relics, the healing effect takes place. The normal procedure is to place the casket on the high altar of any church, presumably to make it visible and accessible to as many people as possible. At SaintLaurent de Cala, the canons are not allowed inside the cathedral because the local administrator is envious and afraid that the visitors will drain his income. As expected, the man is punished, not as brutally as his colleague in Christchurch, however, but rather by suffering an epileptic fit. But when the canons are kicked out, they are favourably received by sa haufdingi sem kastalann hellt 'the chieftain who was in charge of the castle' (Mariu saga: 641$){ }^{3}$ He provides the canons with a large tent where they can arrange the relics appropriately, with lights and decorative

\footnotetext{
2 According to Guðbrandur Vigfússon, it is "no matter of doubt” (ekki efamál) that Lárentíus saga was written shortly after Lárentíus's death in 1331. Guðbrandur suggested a more precise date by highlighting the saga's reference to Árni vaði's election as archbishop, which happened in 1346. Cf. Guðbrandur Vigfússon (1858: xc).

3 The translated text is characterized by some terminological inaccuracies when it comes to provincial and regional matters; no castle has been introduced in the story, and it seems probable that castellum in this case means a town or village. Præpositus castelli, the corresponding phrase from Hélinand's Chronicon, would then be the town mayor.
} 
curtains. The fundraising tour is all about making homes: it has the aim of building a new cathedral, and along the way temporary places of residence are also created. The relics from Laon can turn even a mediocre tent into a glorious place of worship.

When the canons have returned to Laon and all the money raised has been spent on the building project, a second tour is prepared. We are halfway through the story, and it is only now that we are told what relics they have been carrying with them. This is revealed by quoting an inscription from the reliquary: a piece of the Holy Sponge, offered to Christ to drink during the Crucifixion, a fragment from the Holy Cross, a fragment from a cloth, supposedly one that was used to dry the Lord's face, and finally a few hairs of the Holy Virgin. ${ }^{4}$ Images of the Passion are strongly evoked in the description. Before sailing to England, the group makes a few stops in northern France, and the visit to Arras serves as a turning point. Among those who receive the canons in Arras is a blind goldsmith who asks permission to touch the reliquary with his hands and finds out that it is his own handiwork, an early piece he made in his youth. He has heard of some objects that have been kept in the box at one point or another, and this gives him occasion to evoke St Remigius, whose presence seems to change the story rules to some extent. It turns out that among the relics that used to be kept in the casket carried by the canons of Laon is the head of Montanus, the monk who predicted the birth of St Remigius. Just like our goldsmith, Montanus the monk was blind, but he gained sight when Cilinia, the mother of Remigius, sprinkled a few drops of her breastmilk on his eyelids. ${ }^{5}$ The goldsmith of Arras asks the canons to wash their relics in water and then give him the wash water. When drops of the wash water have been sprinkled on the goldsmith's eyelids, he drinks the rest of it and then gains his sight again. After this incident, having people drink the wash water of the relics becomes the preferred mode of performing miracles, and this is how the canons do so most of the time during their tour in England. Access through presence is replaced by access through drinking.

This way of using the Laon relics, and how it may have been understood by those readers in fourteenth-century Iceland who originally read the translation, merits some attention. As it happens, textual evidence for holy relics in Iceland increases from the mid-fourteenth century onwards, mostly starting with Bishop Gyrðir Ívarsson, who served in Skálholt between 1349 and 1360. In the church inventories made by Gyrðir, several examples are found of holy relics in Icelandic

\footnotetext{
4 The inscription is given verbatim in Latin in the Old Norse text, straight from the Chronicon: Spongia, crux domini, cum sindone, cum faciali / me sacrat, atque tui, genitrix et virgo, capilli (Mariu saga: 643). The final item in the list is called into question by Guibert of Nogent (Archambault 1996: 174). 5 Cf. "Remigius saga" (222-223). The Nursing Madonna appears in other Old Norse miracles, for example in a tale where St Bernard of Clairvaux receives breastmilk from the Virgin, not because of illness but because the Virgin wanted to give him the ability to preach (Mariu saga: 195-196); detailed discussion in McGuire (1991: 189-225).
} 
churches. ${ }^{6}$ Unfortunately, details about what type of relics they were or how they were used are entirely missing from these documents, and one must to go a bit further back for more descriptions. ${ }^{7}$ The use of relics was most likely a part of Christian worship in Iceland from the beginning, but it became essential with the translation of the relics of St Thorlak in 1198. The main instigator behind this event, and the rainmaker of Icelandic relic culture, was undoubtedly Bishop Guðmundur Arason. As in so many other respects, Guðmundur was a nonconformist when it came to collecting, consecrating, and applying holy relics. He was even reprimanded by the archbishop for being too active in consecrating various objects - mostly wells - as relics (Biskupa sögur 2: 96). ${ }^{8}$ This might indicate that what is called helgir dómar in the church inventories of Gyrðir Ívarsson around 1350 is not necessarily pieces of a saint's clothing or hair, but probably a much wider category. In the biographies of the Icelandic saints, we do see how relic wash water is sprinkled over the lame and those with wounded limbs in order to heal them. ${ }^{9}$ However, drinking the water does not seem to have been a standard practice in relation to any of them. When the canons of Laon story is translated into Icelandic in the mid-fourteenth century, the modes of engaging in Christian ritual have become more standardized than before, mainly with the spread and increased use of the Eucharist. When the canons of Laon come to Canterbury, a new story rule is added. When a pregnant woman who has been in labour for eight days without success is brought to the travelling group, she is advised to confess her sins first and then drink the relic wash water. Consequently, her baby is born and she quickly regains her health. After the event, the narrator adds the information that from now on, anyone who wanted to drink the relic water had to fulfil two requirements: they had to have formerly belonged to the bishopric that the canons are visiting with the relics, and they had to do penance before drinking (Mariu saga: 647). This is why the canons take an unscheduled detour from Exeter to Salisbury and back, before moving on further west: they meet a disabled person who asks to be cured, but since he is a parishioner from the diocese of Salisbury, he cannot be helped unless both he and the relics are located within his diocese.

The story element of confession as a prerequisite for cure is a familiar one. It is easy enough to associate it with one of the decrees from the Fourth Lateran Council.

\footnotetext{
6 See Diplomatarium Islandicum (III: 84, 86, 89, 105, 160).

7 A rare exception, where a holy relic is precisely described as hond hins hæilaga johannis holensis med armlegginum 'the hand and arm of St Jón, bishop of Hólar', is found in a directory for the church at Breiðabólstaður in Fljótshlíð in 1371 (Diplomatarium Islandicum III: 269).

8 The adjective used by the archbishop to describe Guðmundur is vígslugjarn 'eager to consecrate'. It is not found in other Old Norse sources.

9 “Jóns saga helga” (255-259); "Porláks saga C” (267); "Saga Guðmundar Arasonar” (173). In “Guðmundar saga B", a farmer's eye disease is cured when water from Guðmundur's personal wash basin is sprinkled on his eyes (Guðmundar sögur biskups 2: 55-56).
} 
In 1215, confession was established as an annual obligation for all Christians and an unconditional precondition for receiving the Eucharist. This is strongly emphasized in most of the exempla collections that were composed after 1215 (Le Goff 1992: 79-80). If the relic wash water in the Laon narrative can be taken as a symbolic parallel to the Eucharist, it makes sense as a topic of interest in a mid-fourteenth-century Iceland where the bishops were greatly devoted to expounding on the causal relationship between penance and absolution, confession and Eucharist. It would also be in keeping with the larger evolution of Christian piety as a movement from the tactile to the visual, from relics to Holy Communion. In this case, it is the selection of material for translation, rather than the intention behind the original composition, that matters most. Potentially, this is an example of Christian sacraments as narrative kernels. The story of the canons of Laon certainly gives insight into twelfth-century regional history and spirituality, but it is also one of those instances where viewing a translated text in terms of fidelity to the original version seems less rewarding than analysing it from within the cultural context in which it is embedded.

\section{Bibliography}

\section{Sources}

Diplomatarium Islandicum II. Copenhagen: Möller, 1893.

Diplomatarium Islandicum III. Copenhagen: Möller, 1890.

Guðmundar sögur biskups 2 = Guðmundar saga B, ed. Stefán Karlsson and Magnús Hauksson,

55-56. Copenhagen: Museum Tusculanum Press, 2018.

Heilagra manna søgur, vol. 2, ed. C.R. Unger, 49-158. Christiania: Bentzen, 1877.

Hermanni Monachi = "Hermanni Monachi De Miraculis S. Mariæ Laudunensis," Patrologia latina

156, ed. J.-P. Migne, cols. 961-1018. Paris: Garnier, 1853.

Islendzk æventyri 1, ed. by Hugo Gering. Halle: Buchhandlung des Waisenhauses, 1882.

"Jóns saga helga" = Biskupasögur 1, ed. Sigurgeir Steingrímsson, Ólafur Halldórsson and Peter

Foote, 173-316. Íslenzk fornrit 15². Reykjavík: Hið íslenzka fornritafélag, 2003.

Maríu saga, ed. Carl R. Unger. Christiania: Brögger \& Christie, 1870-1871.

“Nikolaus saga erkibyskups 2," = Heilagra manna søgur 2, ed. C.R. Unger, 49-158. Christiania: Bentzen, 1877.

"Remigius saga," = Heilagra manna søgur, vol. 2, ed. by Carl R. Unger, 222-227. Christiania: Bentzen, 1877.

"Saga Guðmundar Arasonar, Hólabiskups" = Biskupa sögur, vol. 2, ed. Jón Sigurðsson, et al., 1-220. Copenhagen: Möller, 1878.

“Porláks saga C" = Biskupa sögur, vol. 2, ed. Ásdís Egilsdóttir, 251-285. Íslenzk fornrit 16. Reykjavík: Hið íslenzka fornritafélag, 2002. 


\section{Literature}

Archambault, Paul J. 1996. A Monk's Confession: The Memoirs of Guibert of Nogent. University Park PA: The Pennsylvania State University Press.

Guðbrandur Vigfússon. 1858. “Formáli.” In: Biskupa sögur 1, ed. Guðbrandur Vigfússon, et al., v-xc. Copenhagen: Hið íslenzka fornritafélag.

Head, Thomas, ed. 2001. Medieval Hagiography: An Anthology. New York and London: Routledge. Le Goff, Jacques. 1992. "The Time of the Exemplum." In: The Medieval Imagination, translated by Arthur Goldhammer, 78-80. Chicago and London: The University of Chicago Press.

McGuire, Brian Patrick. 1991. The Difficult Saint: Bernard of Clairvaux and His Tradition. Kalamazoo: Cistercian Publications.

Rubenstein, Jay. 2002. Guibert of Nogent: Portrait of a Medieval Mind. New York and London: Routledge.

Turville-Petre, Gabriel. 1959. "Legends of England in Icelandic Manuscripts." In: The Anglo-Saxons: Studies in some Aspects of their History and Culture, ed. Peter Clemoes, 104-121. London: Bowes \& Bowes.

Widding, Ole. 1996. “Norrøne Marialegender på europæisk baggrund.” Opuscula 10: 1-128. 
